\title{
Japanese Literature Course Teaching Research Under College Education
}

\author{
Rizhong Shen \\ Quanzhou Normal University, Quanzhou, Fujian Province, China \\ qztcshenrizhong@hotmail.com
}

Keywords: college education; Japanese literature; curriculum teaching

\begin{abstract}
Curriculum construction is the basic work of colleges and universities, and it is one of the fundamental tasks of teaching basic construction and teaching reform. Japanese literature is an important course for Japanese majors in colleges and universities and its classroom teaching model is in urgent need of reform, to change the traditional approach centered on teacher's explanation, establish the classroom teaching mode of teamwork with teachers' lectures, students' classroom speeches, discussion and summarization, make students become the protagonist of the classroom, help integrate the wisdom of teachers and students, show team spirit, and cultivate students innovative thinking to improve analytical skills and verbal communication skills of students.
\end{abstract}

\section{Introduction}

The Japanese Literature Course is aimed at cultivating graduates who have a strong Japanese basic knowledge and a certain understanding of the history of Japanese literature, Japanese writers and literary schools. The purpose is to help students grasp the context and trends of Japanese literature development from a macroscopic perspective and understand the main literary forms and representative writers and representative works of each period in the development process from a microscopic perspective, so as to achieve the purpose of understanding the nature of Japanese literature and improving students' personal qualities. In addition, Japanese literature is a required subject for the entrance examination for Japanese majors in many universities [1]. This course is also designed to provide students with an understanding of the basics of Japanese literature history, the ability to master the acquired knowledge, and the use of Japanese for interpretation.

The Japanese Literature Course is a newly opened course, and is also one of the key courses in curriculum development planning. However, the teaching staff of the course is still relatively weak and the teaching methods and methods are not perfect. However, we will continue to improve and improve teaching, provide students with better teaching services, and present better classroom results. We will strive to build the course into a premium course in the Foreign Language Institute within five years.

\section{Status Quo of Japanese Literature Teaching in Colleges and Universities}

The history of Japanese literature is a required course for high school students of Japanese majors in the university, and every school pays great attention. However, few scholars sum up the teaching methods. The vast majority of schools use traditional teaching methods based on teacher lectures. Students have fewer opportunities to participate, but only passively accept knowledge [1]. This type of teaching is not conducive to students' creative thinking and analytical ability.

In the teaching of Japanese literary history at the university, the teaching mode that has been used for a long time has been taught in a simple manner, and students rarely participate in it. The self-prepared lecture teaching lesson was copied into the students' minds. The students only took notes and no one raised any objection [2]. However, the results of the final exam are not ideal. In the face of the small-essay questions that need to be played freely, students do not know where to write. Many people can only list literary events. Individual students can discuss and evaluate the topics, but basically all of them are There are no unique insights in dictating class notes, let alone creative thinking. 
The following problems still exist in college education:

1) Lack of clear teaching orientation. The Japanese literature teaching course in vocational colleges is not paid much attention, and it lacks a clear orientation in the current talent training course system. For example, some higher vocational colleges have positioned the course of Japanese literature teaching as an instrumental course, and have not attached much importance to the humanistic connotation of the course of Japanese literature teaching itself. In addition, some higher vocational colleges have positioned the course of Japanese literature teaching as literary education. They believe that this course emphasizes humanistic quality education and has little to do with professional skills education [2]. Therefore, it does not pay much attention to this course, resulting in most of the courses. The Japanese literature teaching curriculum focuses on the form rather than content. It is precisely because the course of Japanese literature teaching itself lacks a clear orientation, which results in the Japanese classroom being neglected, and the related teaching research is rare, and teaching analysis and discussion are very few. In addition, Japanese literature teaching in higher vocational colleges is more random, students lack enthusiasm and initiative in class, Japanese classroom atmosphere is not active enough, and classroom teaching results are not good. In addition, the lack of scientific, rational, and standardized composition in Japanese language classes in higher vocational colleges has led to two phenomena in Japanese language teaching in vocational colleges [2].

2) The teaching mode is fixed and the teaching method is single. The current Japanese classroom teaching methods of higher vocational colleges still follow the traditional teaching methods, namely teaching by teachers and listening to students, teaching models are relatively fixed, and teaching methods are relatively simple. The use of this "full house irrigation" and "reporting textbooks" to teach Japanese in Japanese is not conducive to stimulating students' interest in Japanese learning, nor is it conducive to mobilizing their enthusiasm and initiative, let alone stimulating and cultivating students' innovative thinking and imagination [1]. In addition, the contents of Japanese textbooks in vocational colleges are similar to those in ordinary colleges and universities. There are no new ideas in the contents of the textbooks, and most of them are traditional ideas, lack of appeal, and are far away from real life. The lack of specificity makes it easy for students in vocational colleges to become tired of learning.

3) Lack of effectiveness and poor classroom teaching. The lack of effectiveness of Japanese classroom teaching in vocational colleges, and the ineffective classroom teaching, has become one of the main factors restricting the smooth and effective implementation of curriculum teaching. The concrete manifestation of lack of effectiveness is that the Japanese teaching methods adopted by higher vocational colleges are inconsistent with the characteristics and professional conditions of higher vocational students themselves, which has led to difficulties in the effective implementation of Japanese classroom teaching in higher vocational colleges [3]. Japanese language teaching should be student-centered. If it is allowed to be in a passively accepted position, it will lead to a lack of students' interest in learning and low interest in learning, which in turn will lead to poor teaching in Japanese.

4) Weak teachers and the overall quality need to be improved. At this stage, the strength of teachers in Japanese literature in higher vocational colleges is still relatively weak, and the overall quality needs to be improved. Many Japanese teachers still use traditional teaching concepts for new teaching requirements. They cannot adapt to and meet the needs of students, resulting in poor teaching results. In addition, the scale of enrollment in higher vocational colleges has expanded in recent years, and there are many classes taught by teachers [3]. As a result, Japanese teachers have limited energy for teaching, and there is no extra effort to improve their overall quality and teaching standards.

\section{The Necessity of Improving Japanese Literature Teaching}

These problems, such as the lack of a clear teaching orientation in the teaching of Japanese literature, a fixed teaching model, a single teaching method, lack of effectiveness, poor classroom teaching effectiveness, and weak teacher resources, have seriously affected the teaching of Japanese literature teaching. Effectively, it is necessary to reform the teaching of Japanese literature teaching, 
which is of great significance for better teaching of Japanese literature teaching.

\subsection{Improve the understanding of the effectiveness of Japanese teaching in colleges and universities}

For higher vocational colleges, if we want to improve the awareness of timeliness in Japanese teaching, we must first strengthen our understanding of it. Through strengthening our understanding, we can, to a certain extent, promote the promotion of practical knowledge in the teaching of Japanese in colleges and universities [4]. How to improve the understanding of the effectiveness of Japanese teaching in colleges and universities, the author thinks that should start from the following two aspects: First of all, to carry out the necessary research and analysis of college Japanese course teaching. Second, from different angles and aspects, the author tries to explore and try out the effectiveness of the teaching of Japanese in colleges and universities, and explores and tries to deepen the understanding of the effectiveness of Japanese language teaching in universities.

\subsection{The teaching material selection and professionalism}

For higher vocational colleges, in order to improve the awareness of timeliness in Japanese teaching, it is also necessary to combine curriculum development, teaching material selection, and majors. By combining these three organically, it is possible to clearly position the Japanese language teaching and avoid blindness. In terms of setting up courses, it is necessary to combine the characteristics of higher vocational and technical education in higher vocational colleges, and attach importance to the practicability, scientificity, and rationality of the curriculum, and pay attention to the combination of curriculum setting goals and training objectives [4]. In the selection of teaching materials, it is necessary to combine with the specialties offered by higher vocational colleges and combine with the practice of higher vocational colleges to carefully select Japanese language teaching materials that are in line with the specialties of higher vocational college students. In addition, when designing Japanese language courses and screening Japanese language teaching materials, we must fully consider the characteristics of students in higher vocational colleges and set up related courses according to their characteristics and different needs.

\subsection{Strengthen the cultivation of image thinking and creative thinking}

College Japanese learning has its own particularities, especially higher vocational colleges. It serves the purpose of cultivating advanced professional and technical applied talents. It should focus on cultivating students' creative thinking and teaching Japanese courses in higher vocational colleges [5]. In this regard, teachers should pay full attention to this and strengthen the cultivation of students' image thinking and creative thinking. For example, when Japanese teachers in higher vocational colleges teach students to think about the subject and meaning of an article, they should not set up so-called "standard answers." Instead, they should allow students to fully use their brains to develop their imaginations. Force to find answers from different aspects and different angles.

\subsection{Improve the quality of teachers themselves and improve the teaching team}

Constantly enhance teachers' own learning. Only by constantly updating their knowledge in learning and advancing with the times can teachers master advanced teaching methods, methods, and methods. Only by fully grasping the frontier knowledge and dynamics of majors and curriculum construction can teachers' professional qualities be comprehensive and sustainable [5]. Promote. On the other hand, we strive to achieve "more people in one lesson" and enable more highly educated teachers to participate in the teaching of this course, optimize teaching teams, exchange experience among teachers, and continuously carry out teaching reforms and courses.

\subsection{Increase practice teaching}

It is necessary to pay attention to increasing the proportion of practical teaching in the classroom and intersperse practical teaching in class. In the teaching process, we must incorporate the teaching of class publishing, writing of reading reports, and appreciation of outstanding literary works into the teaching content of the course [6]. By optimizing the course and strengthening extracurricular 
activities, students' comprehensive abilities should be improved, and assessment standards should be formulated according to the training plan, so as to practically ensure the practice.

\subsection{Reform assessment methods}

Actively explore and establish an examination system that conforms to the laws of modern higher education teaching. Diversification of assessment methods, examination content focus on comprehensive ability assessment, the implementation of process examinations, essay examinations and other test modes, according to student performance analysis, continuous improvement of teaching methods, improve the level of teaching [6].

\subsection{Build a web course}

At present, the rapid development of the Internet has, to a certain extent, increased people's access to knowledge. For those who do not understand knowledge, students can make use of the spare time to make inquiries online. On the other hand, teachers can also search for new knowledge on the Internet and supplement the lagging knowledge of the teaching materials. At the same time, the school can also set up a homepage on the campus online [7]. There are plans to take steps to integrate the course syllabus, lesson plans, teaching videos, multimedia courseware, exercises, references, and teaching reforms into the Internet and open it up for free, so that quality resources can be shared and student independence can be achieved. Learning, personalized learning, and online learning provide a platform. In the future, we can further develop the online teaching model and implement online answering questions, online answering questions, online library, and online teaching materials. Make full use of the campus network and conduct interactive teaching.

\section{Measures to Improve the Effectiveness of Japanese Literature Teaching}

\subsection{Provide effective policy support}

In order to improve the effectiveness of Japanese teaching in higher vocational colleges, it is inseparable from the effective support provided by colleges and universities, especially effective policy support [6]. First of all, higher vocational colleges should establish and improve the relevant education system, and introduce relevant policies that are conducive to promoting the improvement of the effectiveness of higher vocational Japanese teaching. Secondly, higher vocational colleges must go up and down, effectively implement and implement these systems and policies.

\subsection{Establish clear teaching goals and increase the aesthetic experience of college students}

For higher vocational colleges, the goal of clear Japanese teaching is to achieve satisfactory teaching results through the realization of Japanese teaching goals. A clear teaching goal can make the direction of Japanese teaching more clearly, in addition, it is also conducive to convergence with its training objectives. Vocational colleges mainly serve to cultivate higher vocational and technical applied talents to meet the needs of all kinds of talents in today's society [7]. Under this premise, the Japanese literature department of higher vocational colleges should have its own characteristics of disciplines, fully embodying its cultural heritage and humanistic connotation. Therefore, in addition to constantly strengthening the necessary basic cultural knowledge education, the objectives of Japanese language teaching and training in higher vocational colleges should also strengthen the corresponding practical ability to use, improve students' cultural accomplishments, and increase their aesthetic experience.

\subsection{Optimize the Japanese classroom teaching style, methods and content}

For students in vocational colleges, in addition to teaching in the classroom, Japanese classroom teaching should also include practical teaching. In addition to mastering the basic scientific and cultural theoretical knowledge, higher vocational students should also conduct more social practice, more exposure to society, and test the theoretical knowledge of science and culture learned from books in social practice. In the process of Japanese teaching in higher vocational education, teachers may organize or arrange students to hold simulated situational training, such as a more formal 
interview presentation, self-recommendation letters written by students after their employment may be required, writing of cover letters, and subsequent job searches for students [7]. Whether you can apply for a successful competitive speech, etc., these are all more basic and practical applied skills. For higher vocational college students, it has greater practical significance and practical value, and will be of higher vocational college students' future. Career planning and development have a greater impact and can play a greater role.

\section{Summary}

In summary, there are still some problems in the teaching of Japanese literature teaching in higher vocational colleges, such as: lack of clear teaching orientation in Japanese courses, fixed teaching mode, single teaching method, lack of practical effect, poor classroom teaching effect, and faculty resources. Weak, overall quality needs to be improved. To solve these problems, it is necessary to reform the teaching of Japanese literature teaching, especially to improve the awareness of Japanese teaching in higher vocational colleges. As for how to improve the effectiveness of Japanese teaching in higher vocational colleges, the author believes that the following three aspects should be followed: Start with: First, improve the understanding of the practical effectiveness of Japanese courses in higher vocational colleges; second, combine the opening of courses, selection of teaching materials, and majors; and third, strengthen the cultivation of visual thinking and creative thinking. In the Japanese classroom teaching of higher vocational education, the effectiveness of Japanese teaching should be improved. The measures to improve the effectiveness of higher vocational Japanese teaching include: first, the college provides effective policy support; secondly, it establishes clear teaching goals and increases the aesthetic experience of college students; again, it optimizes the Japanese teaching style, methods and content of higher vocational education.

\section{References}

[1] X.N. Yu, Necessity of college Japanese curriculum reform in vocational Colleges, Vocational education forum, 2013, vol.2, pp.82-84.

[2] Y.M. Qian, Research on teaching of Japanese literature teaching in vocational colleges in China, Jiangxi Agricultural University, 2013, vol.11, pp. 21-24.

[3] Y.M. Shen, Japanese literature education, Foreign literature education, 2004, vol.4, pp.84-87.

[4] W.W. Hu, New ideas of Japanese grammar teaching mode, Journal of Southwest Agricultural University, 2013, vol.7, pp.86-89.

[5] L.T. Wang, On the study of Japanese grammar teaching, teaching practice research, 2011 vol.4, pp.31-35.

[6] Y.J. Duan, The Importance of Importing Japanese University Literature Education, Journal of Economic Research, 2012, vol.4, pp.19-23.

[7] P.X. Zhang and Y.Ch. Wu, Nearly 10 years domestic Japanese teaching research status quo, Japanese learning and research, 2014.vol.8, pp.21- 25. 